\title{
雄物川の水質の変動特性とそのモデル化 \\ FLUCTUATION CHARACTERISTICS OF WATER QUALITIES \\ IN OMONO RIVER
}

\author{
羽田守 夫* \\ By Morio HANEDA
}

\section{1. 緒言}

河川の水質は，第一に流域の地質などの自然的条件に よりその構成が決まり，第二にこの構成のうえに人為的 污濁源による流出物質がプラスされ，そして，第三に降 雨などの気象条件によって水質変動の性格が特徴づけら れると考えるのが妥当であるう.

しかるに，人口密度が高く経済的発展の著しく進んだ わが国では，流域内の人口や工場などの人為的污濁源 の影響の少ないいわゆる自然河川は，地方にしか残って いないといっても過言ではない. しかも，この人為的污 濁源については，污濁物質の質，量および時間的，空間 的分布が把握しにくいために，水質の中でその影響を分 離して考えることが非常に困難であり，このことが水質 污濁研究の大きな障害になっていると考えられる.

このことは, 現在, わが国の河川の水質研究のうえで 二つの方法が可能なことを示唆している. その一つは, 人為的污濁源による污濁物質の発生量がかなり大きく, 自然的污濁源による発生量を無視できるような河川につ いてであり,このような河川における主要な水質問題は, 有機物や特定の排出物質による污濁であり，この解明の ためには, 発生する污濁物質総量や河川の自浄作用など の研究が第一であろう.この例として, 松本ら ${ }^{1)}$ の阿武 隈川の研究や那須 ${ }^{2}$ の石狩川の研究などが挙げられる. ほかの一つは, 自然的污濁源より発生する污濁物質が, 河川の水質の中で大きな割合を占めると思われる河川に ついてであり,このような河川では, 発生する污濁物質 は降雨や地下水などの流出によってもたらされるもの で, 地質, 地形や流量, 降雨量などの変化による水質変 動の解明が主要な問題と思われる. そして, この解明こ そが前述の人為的污濁の影響の大きい河川の水質の基礎 としても大きな意味を持つものと思われる.この例とし

\footnotetext{
* 正会員 工修 秋田工業高等専門学校講師 土木工学科
}

て, Ledbetter $ら^{3)} の$ Canadian River の研究, Gunnerson $^{4)}$ の Columbia River の研究, Steele ら5)のテ キサス州の諸河川の研究などが挙げられよう.

また, 河川の水質測定は，これまで流量の比較的安定 した時期に採水し, 測定することを基本としてきた.こ れは，採水自体にかなりの労力を要することや採水時期 により水質が大きく変化することを避けるためで, もち ろんそれなりの意味はあるが，河川の持つ污濁物質の流 送作用やその総量 あるいは平均水質などを 把握するに は，必ずしも十分な方法とはいえない，特に，河川の流 量増大時, 寸なわち降雨時には, 污濁物質によりふだん はオーダーの異なるほどの流出量を示す物質もあり,こ の期間の水質変動の把握は, 公共用水域としての河川の 水質評価や許容負荷量などの算定に，欠くべからざるも のになっていると思われる.

このような観点から，著者は，これまで，比較的人為 的污濁源の少ない秋田県中央部を流れる一級河川雄物川 流域について，季節ごとに一か月程度の連続水質測定を 行い, どちらかといえば後者の河川に属する雄物川の水 質と, 流量, 降雨量および気温などの水文因子との関係

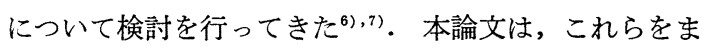
とめ, 季節による水質の変化や流量と水質との関係およ び降雨時の水質変動特性等について基礎的考察を加え, 雄物川のような低有機污濁河川における水質変動の特性 を評価するとともに，本河川に適した水質モデルを提案 し，将来の水質予測のための礎とすることを目的とした ものである.

\section{2. 雄物川流域と調查方法}

雄物川流域の概要を Fig. 1 に示した. 雄物川流域 は, 流域面積約 46 万 ha, 人口約 66 万人, 人口密度約 143 人 $/ \mathrm{km}^{2}$, 流域面積あたり工業出荷額約 5740 万円の わが国では比較的経済的発展の遅れた地域である. 


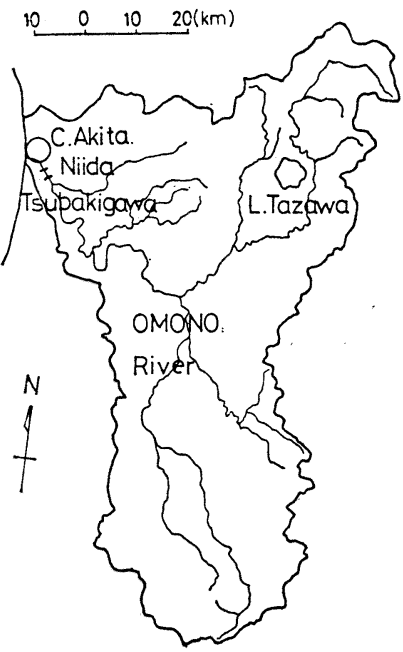

Fig. 1 OMONO River Basin.
水質調查は, 1 日 1 回採水し測定 する連続 調查と し, 採水期間は, 昭和 49 年 10 月〜 昭和 51 年 2 月ま での 1 年 5 か月の 間に季節ごとに計 4 回, それぞれ 30 ４0 数日ずつ合計 135 日である. 以下 それぞれ春期，夏 期，秋期㧍よび冬期 之呼ぶ. 採水地点 は，秋期は雄物川下 流部の椿川地点, そ のほかの時期は同じ
Table 2 Rainfall and Water Flow in the Periods of Investigation.

\begin{tabular}{l|c|c|r|r|r|r|r}
\hline Periods & $\begin{array}{c}\text { Number of } \\
\text { Investiga- } \\
\text { tion Day } \\
\text { (day) }\end{array}$ & $\begin{array}{c}\text { Number of } \\
\text { Rain Day } \\
\text { (day) }\end{array}$ & \multicolumn{2}{|c|}{$\begin{array}{c}\text { Rainfall } \\
(\mathrm{mm} / \text { day })\end{array}$} & \multicolumn{2}{|c|}{$\begin{array}{c}\text { Water Flow } \\
\left(\mathrm{m}^{3} / \mathrm{sec}\right)\end{array}$} \\
\hline Spring & 43 & 19 & 24.4 & 9.2 & 1238 & 553 & 277 \\
Summer & 31 & 16 & 55.0 & 10.2 & 1405 & 275 & 57 \\
Autumn & 30 & 18 & 33.3 & 9.3 & 303 & 171 & 107 \\
Winter & 31 & 27 & 23.4 & 7.3 & 539 & 259 & 101 \\
\hline Total & 135 & 80 & 55.0 & 9.0 & 1405 & 315 & 57 \\
\hline
\end{tabular}

は，雄物川の椿川地点が建設省の流量観測点であり,こ の地点の水位一流量曲線式から求めた流量を使用した. 水質調查期間内の降雨日数, 降雨量および流量について は, Table 2 にまとめて示した.

\section{3. 水質と流量}

河川などの表面水の水質が，流量によって変化するこ とは古くから知られてきた.これは, 河川の流量が表面 流出, 中間流出および地下水流出の三種に大別され, そ れぞれの機構による流出水の流量汇占兴割合や水質特 性が異なることによるためと考えられる.が，水質が流 量によって大きく影響されるという基本的事実には変わ りはなく, 多くの研究者が水質と流量との間の関係を検 討( ${ }^{8)}$ 〜10), さまざまな関倸式を与えている.最も一般的 に用いられる式は, 水質と流量との間に指数関数式が成 り立つとするもので, 次の式で与えられる.

$$
y(t)=a \cdot Q(t)^{b}
$$

ここに, $y(t): t$ 日の水質濃度 $(\mathrm{mg} / l), Q(t): t$ 日の流 量 $\left(\mathrm{m}^{3} / \mathrm{sec}\right), a, b:$ 係数

水質の中で，地質等の自然的污濁源によりもたらされ る項目, たとえば溶解性無機物質などは, 基本的に流量 のみによって規定されていると思われ，式（1）によく 合致すると考えられる.が，一般にさまざまの污濁物質 の流入が考えられる河川では，流量以外に水質を規定す る要因が生じ，したがって，式（1）により求められる 水質は，第一近似值と考えるべきであろう．水質汇影響 を与えるほかの要因に，たとえ降雨があり，降雨強 度，継続時間などの変数により同じ流量であっても水質 は異なることが考えられよう。

Table 1 Water Qualities in OMONO River ${ }^{17)}$.

\begin{tabular}{|c|c|c|c|c|c|c|c|c|c|c|c|c|}
\hline Month & 1 & 2 & 3 & 4 & 5 & 6 & 7 & 8 & 9 & 10 & 11 & 12 \\
\hline $\mathrm{pH}$ & 7.4 & 7.2 & 7.2 & 6.7 & 7.0 & 7.2 & 7.2 & 7.1 & 6.9 & 6.6 & 6.3 & 6.7 \\
\hline $\mathrm{SS}(\mathrm{ppm})$ & 17.6 & 30.5 & 19.4 & 26.0 & 24.7 & 22.8 & 15.3 & 28.6 & 70.5 & 27.2 & 43.2 & 22.8 \\
\hline $\mathrm{Cl}(\mathrm{ppm})$ & 15.9 & 19.7 & 15.3 & - & 23.6 & 26.1 & 17.4 & - & 14.5 & 13.4 & 14.1 & 15.4 \\
\hline $\mathrm{NH}_{\mathrm{g}}-\mathrm{N}(\mathrm{ppm})$ & 0.10 & 0.40 & 0.28 & - & 0.37 & 0.20 & 0.47 & - & 0.58 & 0.76 & 0.94 & 0.82 \\
\hline $\mathrm{COD}(\mathrm{ppm})$ & 1.24 & 2.92 & 1.85 & - & 0.65 & 1.86 & 0.76 & - & 0.63 & 0.52 & 0.44 & 0.12 \\
\hline $\mathrm{BOD}(\mathrm{ppm})$ & 2.23 & 2.05 & 3.02 & 1.95 & 0.89 & 1.01 & 1.00 & 1.11 & 0.75 & 0.86 & 1.02 & 1.15 \\
\hline $\mathrm{Q}\left(\mathrm{m}^{3} / \mathrm{sec}\right)$ & 202 & 240 & 245 & 459 & 154 & 83.1 & 59.7 & 93.1 & 248 & 234 & 351 & 261 \\
\hline
\end{tabular}


Ledbetter $ら^{31}$ は，独立変数としては同じ流量を用い ながら,式（1）の倸数 bを変数と考え次の式を導いた。 $b=P \cdot Q^{n}$

ここに, $P, n:$ 係数

が, この式でも十分ではなく, 流量と変数 $b$ との間に 欠けるものとして, 流量の過去の経過を表わす指標を考

慮し, これを先行流量と名ゔけて次の式を導いた.

$$
\begin{aligned}
& b=f+g \cdot \log A_{q}+h \cdot Q^{n} \\
& A_{q k}=\sum_{i=1}^{30} Q_{i} / i \quad \ldots \ldots \ldots \ldots . . .
\end{aligned}
$$

ここに, $A_{q}$ : 先行流量, $f, g, h:$ 回帰係数, $i: k$ 加ら 先の日数

そして, 式 (3) により変数 $b$ がかなりよく整理でき

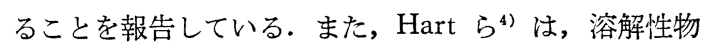
質負荷 $L$ を次の形で表わす式を導いた.

$$
L=a_{1} \cdot Q_{G}+a_{2} \cdot Q_{I}+a_{3} \cdot Q_{S}
$$

ここに, $Q_{G}$ : 地下水流量, $Q_{I}$ : 中間流量, $Q_{S}$ : 表面流 量, $a_{1}, a_{2}, a_{3}$ : 係数

そして, Hopland の Russian River の水質研究で, 式（5）を用いてよく水質を表わせることを示した.

河川の水質变動倿対する独立变数を数式化するうえ で, 流量以外の変数を取ることには, 資料の入手や定量 化の点から困難が多い.そこで, 式 (2)〜 (5) のような基 本的に流量のみを変数とする数式化が, おもに溶解性無 機物質の流出機構の解明を第一に行われていると考えら れる.これらは, 溶解性や浮遊性などの污濁物質の存在形 態の違いにもよるが貴重な試みであり, 特に式 (5)のよ うな流量の分割は, 溶解性のみでなく浮遊性物質の評 価, 予測にも適当な方法となる可能性があろう. が, 実 際上, 流量に占める各流出量の予測には限界があると思 われ，この面での検討がさらに必要であろう. 本論文で は, まず流量と水質の変動のパターンを知ることとし, 式（1）を基本として検討を行った.

\section{4. 水質の変動特性}

\section{（1） 溶解性無機物質}

a) 総 硬 度

総硬度は, 雄物川では主として地質に由来するものと 思われ, 自然による水質変動を見るには適した項目であ ろう. Fig. 2 に, 総硬度と流量を式 (1) に基づいて両 対数紙上にプロットして示した.これによると, 総硬度 と流量は，ほぼ式 (1) を満足して増減する傾向が認め られる. 全資料による回帰式は次のように求められた.

$$
y=102.2 \cdot Q^{-0.303} \quad(r=0.866)
$$

ここに, $y:$ 総硬度 $(\mathrm{ppm}), r:$ 相関係数

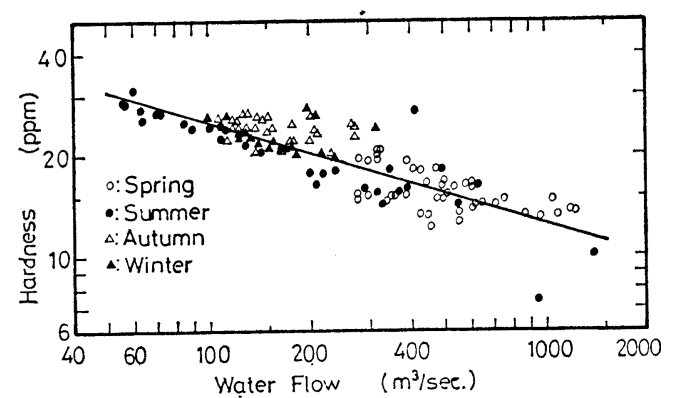

Fig. 2 Relation between Hardness and Water Flow.

が,この関倸は, 必ずしも一直線ではなく, 資料は少 ないが流量範囲を長軸とする棈円を描くと考える方が妥 当と思われる. すなわち, 総硬度は, 融雪期を境任希釈 されて濃度が低下し,この傾向が夏期ごろまで続く，夏 期には大きなばらつきも見られるが, 秋期になると濃度 はいくぶん上昇し, 冬期にもこの若干高い傾向をほぼ維 持してまた春期に継続するというような一連の棈円形曲 線を描いていると考えられよう。もちろん,これには, 融 雪や降雨による一連の流量の増減に伴って生じる濃度変 化も含まれ，これらもより小さなサイクルの曲線を描い ている. Fig. 2 はそれらの合成としての結果を表わし, それだけ複雑な曲線形を示している.が, Gunnerson ${ }^{4}$ が示したように，大陸とわが国の河川では，気象などの 違いによりその表われ方は異なるが, 流量と水質には, 基本的に一年を周期とする棈円形曲線の関係があると思 われ，雄物川についてもこれは十分に予想されよう。

b）総アルカリ度

Fig. 3 に, 総アルカリ度と流量との関係を示した. これによると, 総アルカリ度も総硬度と同様に, 一応式 （1）の関係を満足して増減するが，やはり一直線で表わ すよりも棈円を描くと考える方が妥当である. 棈円の形 や季節的変化は総硬度とほぼ同じであるが, 流量が大き い所での濃度のばらつきが総硬度と比べて少ないのが一 つの特徵といえよう. 総硬度同粶, 全資料による回帰式

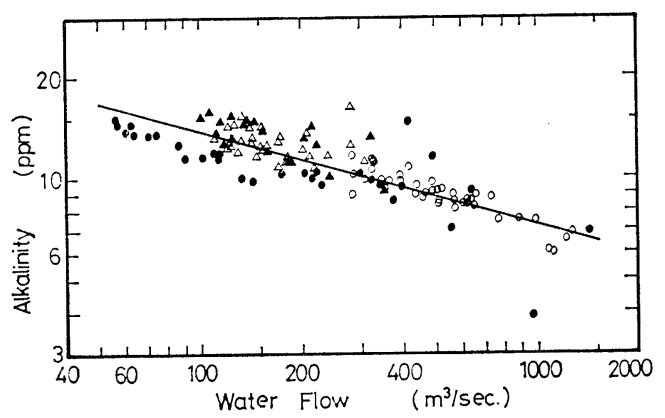

Fig. 3 Relation between Alkalinity and Water Flow. 


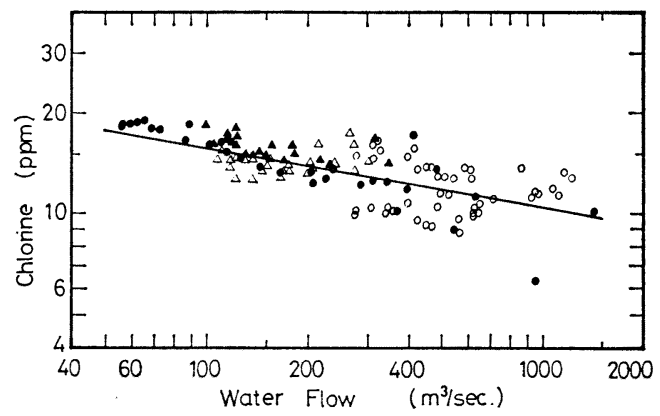

Fig. 4 Relation between Chlorine and Water Flow.

は, 次のように求められた.

$$
y=49.7 \cdot Q^{-0.278}(r=0.814)
$$

ここに, $y:$ 総アルカリ度 $(\mathrm{ppm})$

c) 塩素イオン

Fig. 4 に，塩素イオンと流量との関係を示した. 塩 素イオンについても, 式 (1) の関係をほぼ満足するが, これも総硬度同様棈円を描くと考えるのが妥当である う.が,この楕円形は, 総硬度などと異なり流量が少な いときは棈円軸が短く, 流量が約 $200 \mathrm{~m}^{3} / \mathrm{sec}$ を越える と急に大きくなり, 濃度もかなりばらつく傾向を示して いる. 日本海側の河川水には, 風送塩が影響し, 特に春 の融雪時にピークを示すといわれるが ${ }^{18)}$, 前述の塩素イ オンの傾向には，この風送塩の影響が含まれていると思 われる. 式 (1) に基づく回帰式は, 次のように求めら れた。

$$
y=36.6 \cdot Q^{-0.182}(r=0.697) \cdots
$$

ここに, $y:$ 塩素イオン $(\mathrm{ppm})$

d) 硝酸性窒素

河川の栄養源となる窒素は下水などのほかに自然界に も存在し ${ }^{11)}$ ，その源をたどることは困難である.Fig. 5 に, 流量と硝酸性窒素との関係を春期と夏期について示 した. 硝酸性窒素は，流量との関係はあまり見られず， 流量が増したときに大きくばらつく傾向が認められる。 硝酸性窒素も, 総硬度と同様なかなり短軸の大きい棈円

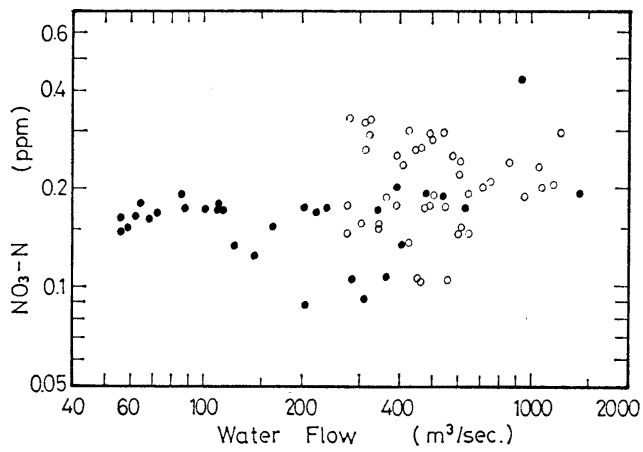

Fig. 5 Relation between Nitrate Nitrogen and Water Flow.
を描くと考えることもできるが，資料が少なく，流量と の関係は明確に認められないとするのが妥当であろう.

硝酸性窒素を除けば，おもな流出源を地質などの自然 的污濁源によると思われる溶解性無機物質は, 降雨や融 雪による希䣋, 温度や長い滞留時間などによって高濃度 を示す地下水およびその流量に占める割合の変化などの 長期にわたる自然のサイクルにより大きな影響を受けて いると思われ, 以上はそれを示していると思われる. こ れを季節の差と考えれば, 溶解性無機物質濃度は, 日単 位の水質で考えれば主として流量のみによって規定され ると思われ，季節差をいかに評価，予測するかが主要な 問題と考えられる.

\section{（2）浮遊性無機物質}

\section{a）濁度}

雄物川の濁度と流量との関倸を Fig. 6 に示した.こ れによると, 濁度は溶解性物質とは基本的に異なり,一 般に流量の増加とともに急激に増大寸る. 無降雨期の濁 度は, 一応, 式 (1) の関係を満足すると思われるが, 降雨時には同じ流量でも大きな違いがあり, Fig. 6 に はこれを区別して示した.また, 融雪期は, 降雨時とは 逆に流量減少とともに濁度は大きく減じ, この時期特有 の現象が認められる．これをまとめると，河川への濁質 の流出は大きく三つの時期に分けて考えられる. 第一 は, 濁度が急増する降雨時, 第二は無降雨期および第三

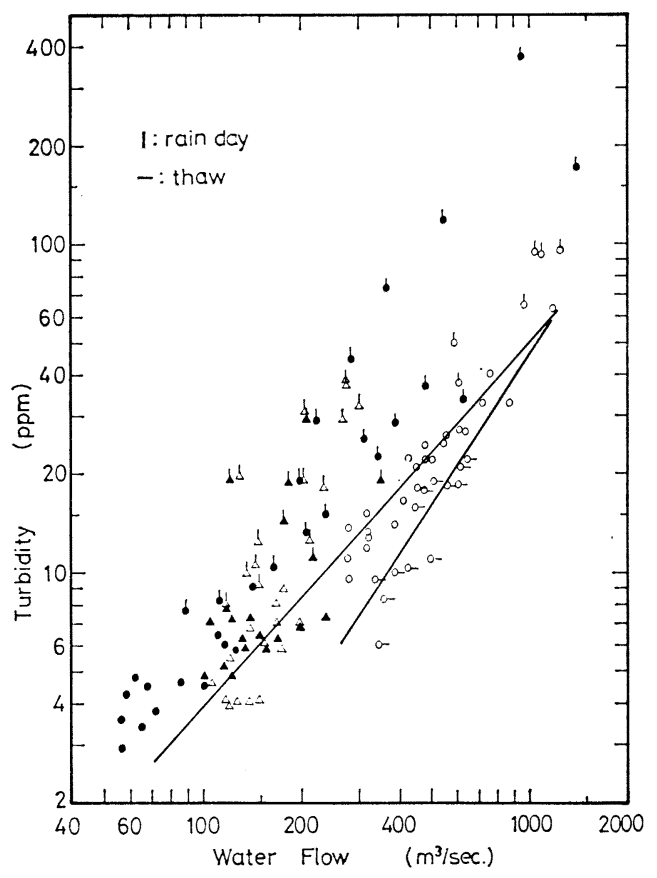

Fig. 6 Relation between Turbidity and Water Flow. 
は急激な濁度減衰をもたらす融雪期である．この中で， 第二および第三の場合の濁度は, 式 (1) の関係をほぼ 満足して増減し，これが河川の濁度を考えるらえで基本 となるものと考えられる. これらの回帰式は, 次のよう に求められた.

無降雨期 $y_{1}=0.0349 Q^{1.04}(r=0.964)$

融雪 期 $y_{2}=0.00125 Q^{1.52}(r=0.861)$

ここに， $y_{1}, y_{2}:$ 濁度 $(\mathrm{ppm})$

これに対し降雨時は, 降雨の量, 強度, 継続時間およ び降雨までの天候の履歴などが影響するためかかなり濁 度はばらつき, 特に豪雨の場合に著しく認められる.

このように, 河川の濁度を三つの時期に分類して考え れば, 流量に対して大きなばらつきを示す濁度もかなり よく整理して考えることが可能であり, 表面流出による 影響の大きい水質を考えるうえで，このような分類の方 法は非常に重要であると思われる.

b) 浮遊物質 (SS)

SS と流量との関係を Fig. 7 に示した.これによる と両者の関係は, 濁度の場合とよく類似していることが 認められる. したがって, SS の場合も, 融雪期は濁度 の場合のような急激な濃度減少は示していないが,一応 降雨時, 無降雨期および融雪期の三つの時期に流出機構 を分類して考えることが.できる. Fig. 1 の二つの直線 は，それぞれ無降雨期と融雪期の回帰直線で，これがい わば SS 変動の基本であり, 次のように求められた.

無降雨期 $y_{1}=0.0139 Q^{1.27}(r=0.959)$

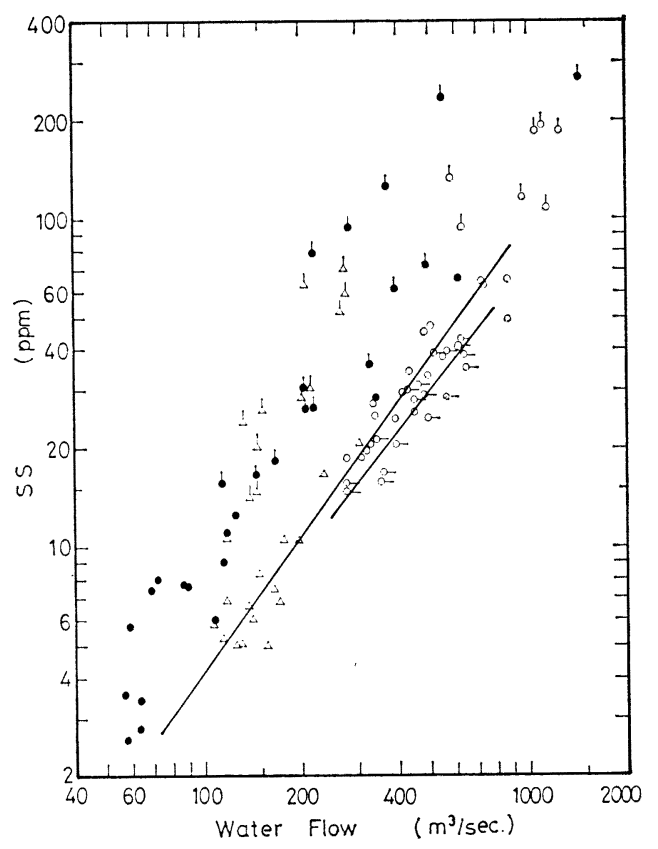

Fig. 7 Relation between Suspended Solids and Water Flow.
融雪期 $y_{2}=0.0113 Q^{1.27}(r=0.912) \cdots \cdots(12)$ ここに, $y_{1}, y_{2}: \mathrm{SS}(\mathrm{ppm})$

以上のような水質と流量との関係は, 濁度や SS にほ ぼ共通しており, 表面流出成分による影響の大きい水質 を, 降雨のない場合の濃度を基本とし, 降雨のある場合 にはこれに降雨による流出量がプラスされると考えるこ とは，污濁物質の流出機構についての物理的な意味もあ り，妥当なものと考えられる.

\section{（3）有機物質}

a) $\mathrm{BOD}$

Fig. 8 に, BOD と流量との関係を示した.これによ ると, $\mathrm{BOD}$ は季節的変動は若干認められるが, 流量と はほとんど無関係に変動している.これには, BOD が 自然污濁のみでなく, 人為污濁や自浄作用などを受けて いることにも関係すると思われる. が，雄物川について は, BOD と自然污濁や流量との因果関係を求めるには 資料の信頼性などから問題があり, その評価や予測は非 常に困難と思われる.

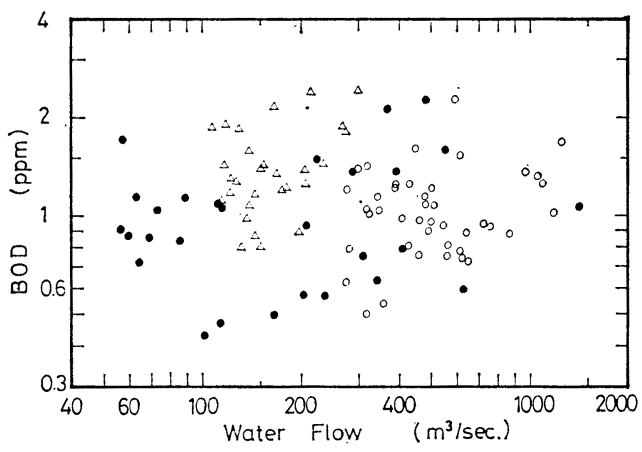

Fig. 8 Relation between Biochemical Oxygen Demand and Water Flow.

b) $\mathrm{COD}$

Fig. 9 に, COD と流量との関係を示した.これによ ると, COD は一般に流量が増すと増大し, 特に降雨の ある場合に著しいなど濁度などと同様な傾向が認められ る.が, 冬期は, 濁度などとは違った現象が見られ, 融 雪や気温のためかかなり 小さな值を示した. Fig. 9 に よると, 無降雨期, 融雪期および冬期の COD と流量と の間には, 溶解性無機物と同様な棈円関係を仮定するこ とも可能であるが, 資料が少なくさらに検討が必要であ ろう.

このように複雑な変動を示す $\mathrm{COD}$ をここでは流 量との関係から次のように分類して考えることにする.

すなわち, 濁度等と同様に, 降雨時, 無降雨期および融 雪期の三時期と第四に COD の小さい 冬期を加えた四 時期である.したがって, 雄物川の COD は, 第二, 第 


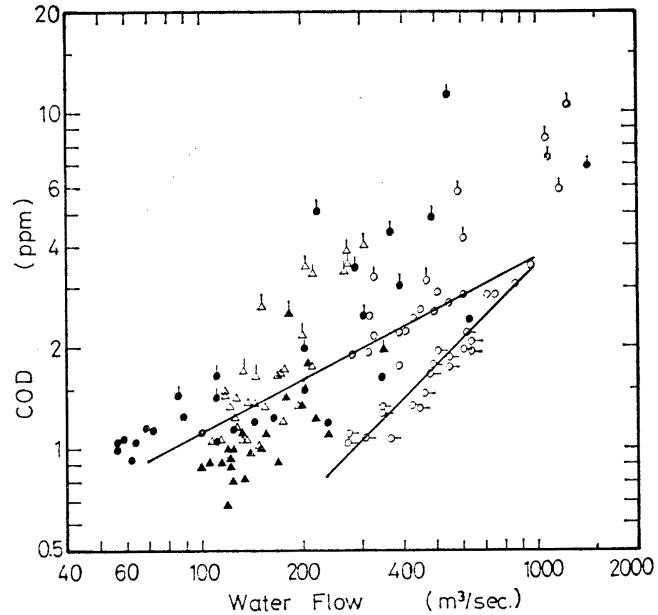

Fig. 9 Relation between Chemical Oxygen Demand and Water Flow.

三および第四の場合を基本とし，降雨時にはこれに降雨 による流出物質がプラスされて形成されると考えるのが 妥当であろう. 無降雨期と融雪期の式 (1) に基づく回 㴆式は, 次のように求められた.

無降雨期 $y_{1}=0.100 Q^{0.523}(r=0.914)$

融雪期 $y_{2}=0.00479 Q^{0.948}(r=0.945) \cdots(14)$ ここに, $y_{1}, y_{2}: \operatorname{COD}(\mathrm{ppm})$

以上は，COD-Mn についてであるが，同様に COD$\mathrm{Cr}$ についても検討を行った. COD-Cr は, 流量との関 係は基本的に COD-Mn の場合と同じと思われるが, 変動の幅が大きく, 明確な関係を見い出すのは困難と思 われた.そこで,ほぼ有機物全量を示すといわれる COD -Cr については, COD-Mn との関係から検討すること を試み，Fig. 10 に両者の関係を示した.これによる と, COD-Cr は, COD-Mn の約 3 倍強の值を示し, ほぼ直線回帰が可能であった. 求められた回帰式は, 次 のとおりである.

$$
y=3.20 x \quad(r=0.89)
$$

ここに, $y: \mathrm{COD}-\mathrm{Cr}(\mathrm{ppm}), x: \mathrm{COD}-\mathrm{Mn}(\mathrm{ppm})$

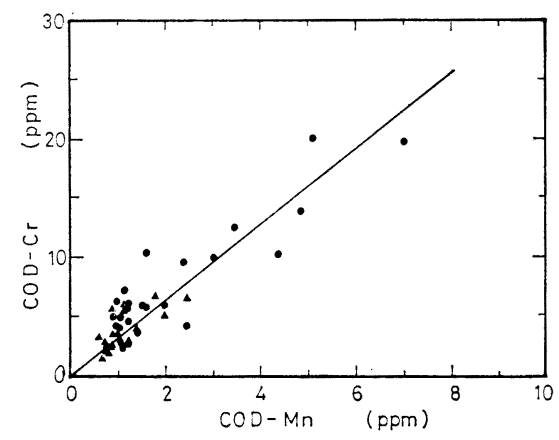

Fig. 10 Relation between COD-Mn and COD-Cr.
COD-Cr が全有機物量を表わすと考えれば，雄物川 のような人為的污濁源の少ない，低有機污濁河川におけ る有機物量を考えるうえで，一つの目安となるものと考 えられる。

なお, 河川の水質を考えるらえで, 流量と水質の関係 だけでなく流出量との関係も重要である.が, 流出量は 流量と水質の積であり, 以上のような諸関係は流出量と の間にもすべてあてはまり，かつより朗確になるものと 思われるので, ここでは省略した.

\section{5. 水質モデル}

\section{（1）溶解性無機物質}

前述のように, 河川の溶解性物質は, 一般に流量が増 せ濃度核減少する。したがって，水質変動は，水質と 流量との間の基本式（1）を基にして直線回帰するには 問題もあるが，季節変動を含めた棈円形を描くと考える とよく説明できることが示された.

Gunnerson $^{4)}$ は, アメリカ Columbia River 流域の Snake River の Wawawai 地点における総硬度と流量 との関係について Fig. 11 のように示した.これは， 総硬度と流量とが年間を通して棈円ドーナツ型を描くこ とを示すもので, 河川水の溶存無機物が基本的にこのよ うな関係にあることを報告している。この棈円ドーナツ 型は，その形とドーナツの点が異なるとはいえ，雄物川 の溶解性物質に関する水質と非常によく類似している.

溶解性物質と流量との楕円関係は，次のように説明で きる. 一般に最大水質濃度は流量が最小のとき生じる. 融雪期には增えた流量により希釈されて濃度は減少 し，またこの時期の高流量により流域の滞積物質はほ とんど流出してしまう。したがって, 夏期には濃度が減 少する，低流量期には，流量に占的る地下水の割合が大 きく，秋から冬期にかけては比較的高い濃度が維持され る.このように考えれば，河川の溶解性物質が一年を周 期とする気象の影響を受けて増減することがある程度物 理的にも説明できよう．したがって，溶解性物質の水質

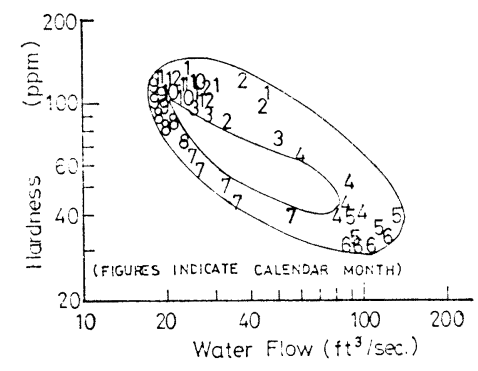

Fig. 11 Total Hardness and Water Flow"). 


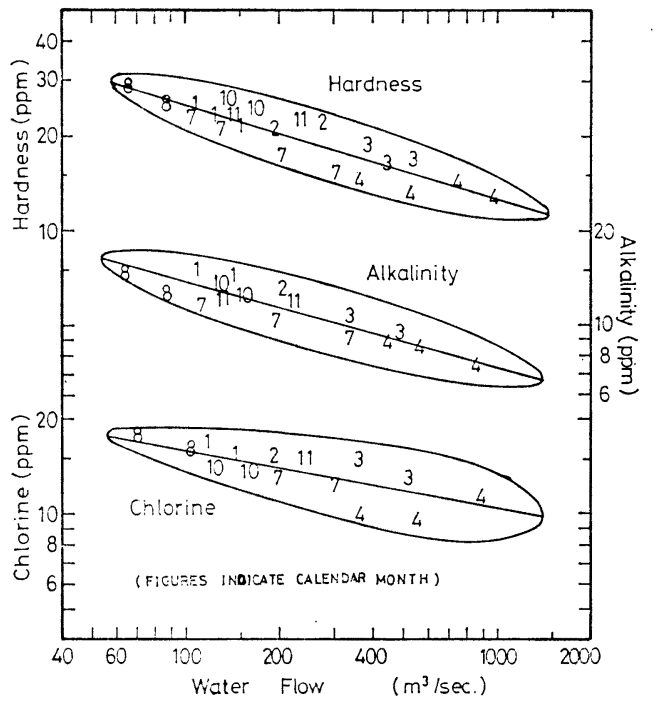

Fig. 12 Hardness, Alkalinity, Chlorine and Water Flow.

モデルは水僙と流量との楕円関係を基に，季節ごとの式 （1）に基づく回帰式の作成にあると思われる. Fig. 12 には，雄物川の溶解性物質について, Fig. 11 と同様な 月別水質值を模式的に示した.

\section{（2）浮遊性無機物質之 COD}

4. における考察を基に, 浮遊性物質による影響の大 きい水質は, 式 (1) を基本とし降雨時にはこれに降雨 による流出量がプラスされるものと考え, 次の式を導い た。

$$
y(t)=a Q(t)^{b}+f(R)
$$

ただし，

$$
\left\{\begin{array}{l}
f_{1}(R)=c \bar{R}(t)+d \\
f_{2}(R)=c \bar{R}(t)^{d}
\end{array}\right.
$$

ここに, $y(t): t$ 日の水質 $(\mathrm{ppm}), f(R):$ 降雨による 流出関数, $\bar{R}(t): t$ 日の影響降雨量 $(\mathrm{mm} /$ 日) $, c, d:$ 回帰保数

雄物川流域のように広大な流域では, その日の水質に 影響を与える降雨は, その何日か前にもわたって影響し ていると思われ, 影響降雨量は, これを考慮した降雨量 とし, 次のように定義した.

$$
\bar{R}(t)=\sum_{\tau=0}^{a} w(\tau) \cdot R(t-\tau)
$$

ここに, $w(\tau): \tau$ 日の降雨の重み $(-), \tau:$ 遅れ日数 (日), $R(t-\tau): \tau$ 日前の降雨量 $(\mathrm{mm} /$ 日) $, \alpha:$ 影響日 数 (日)

ある日の降雨の重みは, 水質と降雨量との相互相関係 数から合計して 1.0 になるよう比例配分して求めた. また，影響日数は，相互相関係数の比較的大きい期間の 日数とし，ここでは，その形を検討したうえで 2 日間と

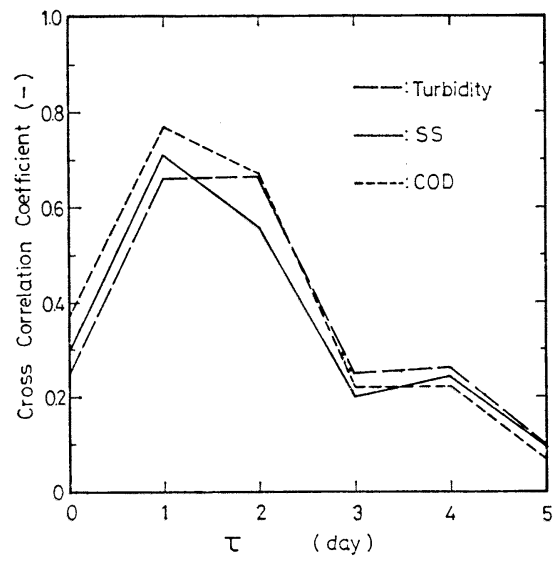

Fig. 13 Cross Correlation between Water Quality and Rainfall.

した.すなわち，

$$
\begin{aligned}
& \phi_{y R}(\tau)=\frac{\sum_{t=0}^{N} y(t) \cdot R(t-\tau)}{\sqrt{\sum_{t=0}^{N} y(t)^{2} \cdot \sum_{t=0}^{N} R(t)^{2}}} \\
& w(\tau)=\phi_{y R}(\tau) / \sum_{\tau=0}^{\alpha} \phi_{y R}(\tau) \ldots \ldots \ldots . . .
\end{aligned}
$$

ここに, $\phi_{y R}(\tau)$ : 水質と降雨量との相互相関係数 $(-)$, $N:$ データ数, $y(t): t$ 日の水質 $(\mathrm{ppm}), R(t): t$ 日の 降雨量 $(\mathrm{mm} /$ 日).

$w(\tau)$ とょについては, 一例を Fig. 13 に示した. 式（16）の水質モデルにより水質の評価を行う場合, $\bar{R}(t)$ が $1.0 \mathrm{~mm}$ 以下の場合は式中の右辺第二項は 0 と し，流量のみにより水質が規定されると考えた。また， $t$ 日の水質を評価するには, 流量は当日のを用いて右 辺第一項の值を求め, $(t-1)$ 日までの過去の一定期間 の資料から式 (20)，(21）により $w(\tau)$ を決めて $t$ 日の $\bar{R}(t)$ を式 (19) により計算し, 式 (17) または (18) か ら最小二乗法により最適な係数 $c, d$ を求めて $f(R)$ を 算出し, 式 (16) に代入して $y(t)$ を算定するといら方 法によった. すなわち， $t$ 日の水質評価には，なんらか の形で当日の流量と降雨量は求められているものと仮定

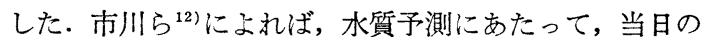
流量や水質を用いる方がより正確な予測ができることが 示されており，現実的な方法といえよう.

降雨による濁質の流出機構は, 季節や降雨ごとに異な ることも考えられる. そこで, 降雨による水質の増分に ついては式 (17) と（18）の両式を用いて比較検討した. また, 降雨ごとの水質の差についても, $w(\tau)$ や係数 $c$, $d$ の決定にあたって過去の資料を一定期間ずつ移動さ せる場合と過去の全資料を使って求める場合の二とおり を試み比較検討することにより考慮した. が，基本とな る流量と水質の関倸の季節的な変動については, 資料不 


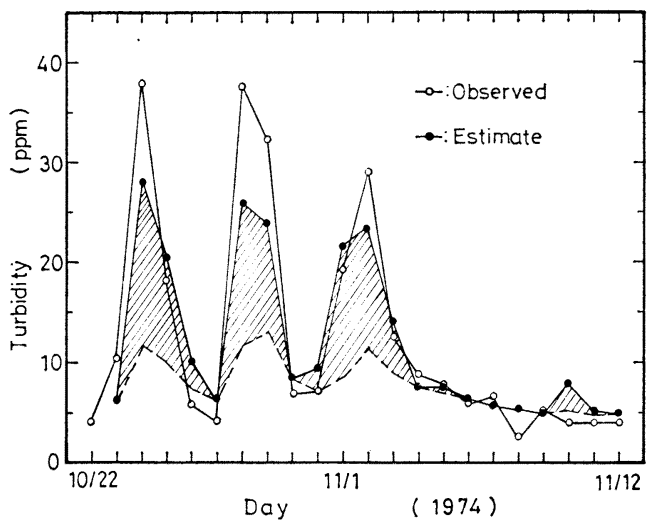

Fig. 14 Estimate of Turbidity.

足もありここでは一定なものと考えた．

結果の一例を濁度について Fig. 14 に示した.これ は秋期の場合で, 式（16）の右辺第一項には式（9）を あてはめ, 第二項については式 (17) を用い過去 7 日間 の資料を一定期間として移動させながらそのつど $w(\tau)$ や $c, d$ を決定して, 式 (16) により水質を評価したも のである.図の斜線部分は,第二項の降雨による増分を示 している.このときの測定值と評価值との残差の標準偏 差 $\sigma$ と重相関係数 $r$ は，それぞれ $4.55 \mathrm{ppm}$ および

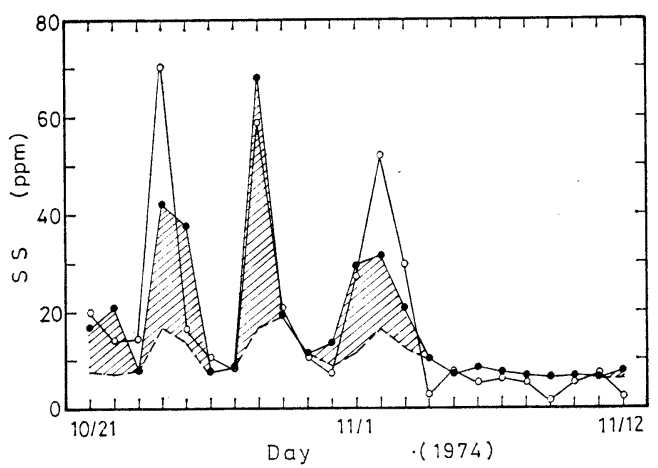

Fig. 15 Estimate of Suspended Solids.

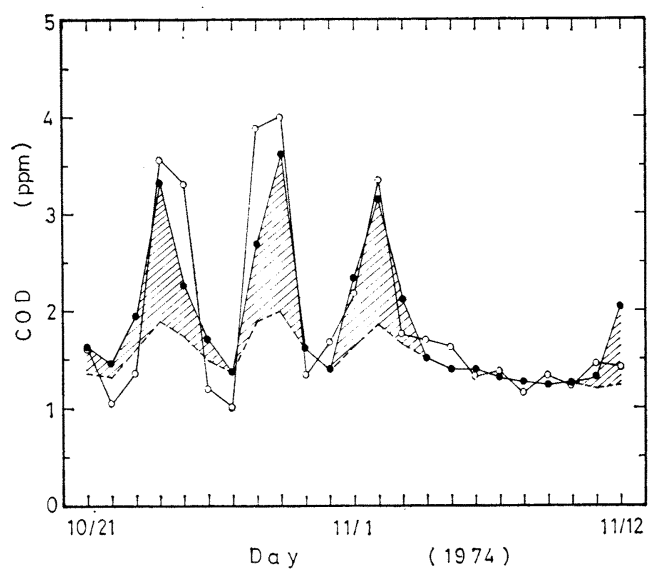

Fig. 16 Estimate of Chemical Oxygen Demand.
0.953 であった.これによると, 式（16）による濁度の 評価は極大值や極小值への追随性は良好ではないが，降 雨のある場合の水質変動を比較的よく説明できており， 基本的に濁度変動をよく表現していると考えられる。

Fig. 15 には，秋期の SS についての適用例を示し た.これは，式（11）と（17）を用い，過去 5 日間の資 料を一定期間として移動させて諸係数を決め, 水質を評 価したものである. $\sigma$ と $r$ は，それぞれ $9.59 \mathrm{ppm}$ と 0.855 であった. これによると, 評価值は, 極值への追 随性が良好でないが全体として SS 変動によく対応して 増減しており，降雨による増分を考慮することの有効性 を示していると思われる.

次に, Fig. 16 には, 秋期の COD についての適用 例を示した.これは，式（13）と（17）を用い，過去の 全資料を用いて水質を評価したものである。 $\sigma$ と $r$ は， それぞれ $0.433 \mathrm{ppm}$ と 0.899 であった.これによる と，評価值は，極大值前後ではあまりよく合致していな いが，濁度などと同様に全体として水質変動によく追随 しており，式（17）による COD 評価が効果的なことを 示している.

極大値前後で合致性がよくないことは以上の例化共通 浔認めらるが，これは表面流出成分による水質は時間 変動が大きく ${ }^{13)}$ 日水質で水質を表わすことが難しいこ と, 降雨量に地域差があることや式の関数形や係数の決 め方など，さらに検討が必要なことなどに関係すると思 われる. 特に以上の例は，いずれも 30 日間の資料から 評価を行ったもので, 実際の適用にあたってはもら少し 長期間の資料を集めて検討する必要があろう．が，逆に この程度の短期間の資料でも，持っている情報を取り出 しながら評価していけば, 変動の激しい表面流出成分も 特に降雨による流出量を考虑することによりかなりよく 表現できるわけで，この意味でもよりいっそうの資料の 蓄積と適用例の検討が重要と思われる.

\section{(3) 考察}

流域の地質が河川の 無機水質に与える影響について は, Beston $~_{\left.{ }^{14}\right)}$ が式 (1) を基に係数 $a, b$ を地質の種 類による変数と仮定し, 重回帰分析により検討してい る. Haith ${ }^{15)}$ は, 流域の土地利用と河川の窒素, リンお よび浮遊物との関係を同様な方法で分析し, 窒素につい てはかなりよく整理できることを報告している。これら は，おもに非点源から流出してくる污濁物質を, 統計的 手法を用いて年間流出量や予測についての情報を得よう とするもので ${ }^{16)}$ ，今後の水質管理や水利用計画にとって より重要な意味を持つものと考えられる.

ここで提案した水質モデルは，水質の評価にあたって 式（1）に基ゔく水質と流量との基本的関係および当日 
の流量や降雨量については, なんらかの形で求められて いることを前提としており，污濁物質の流出機構の評価 を主眼とした方法である．また，雄物川は低有機污濁河 川とはいえ, なんらかの人為污濁の含まれる河川である ことや水質資料の数がまだ少ないことなどから，この応 用は限定して考えなければならない. が，ここに示した 方法は, 低有機污濁河川における水質変動をよく表わし ていると思われ，同様な流域を持つ河川や有機污濁河川 の水質の基礎としても適用可能と思われる.

\section{6. 結䨐}

雄物川の水質変動について, 短期間ではあるが年間を 通した季節ごとの連続水質調査を基に，水質と流量や降 雨量との関係について検討を行った. また，本河川に適 した水質モデルを提案し，その応用例について考察し た. 結果を要約すると次のとおりである.

（1）雄物川流域のような人為的污濁源の少ない河川 では, 水質は, 流量や降雨量などの水文学的因子と密接 な関係を持ち，これらに対応して変動する傾向が認めら れる.

（2）河川の水質の中で主として溶解性無機物は，日 単位で考えればほぼ流量との関係のみで水質が決定され ていると思われる. これは, 両対数紙上で一年を周期と する棈円を描くと考えるのが妥当であり，季節差を考慮 して時間スケールを短縮すれば, $y=a Q^{b}$ の指数関数式 で近似される.

（3）表面流出成分の影響の大きい水質は, 降雨時に 大きく変動する傾向がある. これを考慮するには, 無降 雨期における水質と流量との指数関数を基に, 降雨時に はこれに降雨による流出分がプラスされて水質が形成さ れると考えるのが妥当で, 流量に関してかなりばらつく 資料をかなりよく整理して考えることが可能となる.

(4) 融雪期の水質は, 流量との関係は基本的に指数 関数で表わされるが, 融雪水に希釈されてほかの時期と は異なった傾向が認められる.

（5）水質と流量および降雨量との関係についての考 察を基にここで提案した水質モデルは, 河川の水質変動 をかなりよく表現できることが認められた．が，季節の 差, モデルへの資料の入力の方法や関数形等について は, さらに検討が必要であり, 資料を蓄積して十分検討 すべきであろう。

なお, 今後の課題は, ここでは表面流出成分を降雨量 を用いて表わす方法をとったが，この適用例を増やして 検討するとともに, Hart ら ${ }^{4)}$ が示した流量の分割とこ れに対応する水質を求める方法に基づいて, 污濁物質の 流出機構を究明することと考えられる.
おわりに, 本研究に関して終始適切なるご指導とご助 言をいただいた東北大学の松本順一郎教授に対し, 深甚 なる謝意を表します.

調査上協力を惜しまなかった当時の本卒研生に対し， 心から感謝の意を表します. また, 資料を提供していた だいた建設省秋田工事事務所, 秋田地方気象台および採 水でお世話いただいた秋田市仁井田浄水場の関係各位に 厚く御礼申し上げます.

\section{参 考 文 献}

1）たとえば, 松本順一郎・市川 新・大沼正郎・中村立正： 阿武隈川の自浄作用 (1), 下水道協会誌, Vol. 10, No. 107, pp. 2 12, 1973.

2）那須義和：河川の水質污濁解析と水質予知へのアプロー チ, 第 8 回水質污濁研究に関するシンポジウム講演集, pp. $31 \sim 46,1974$.

3) Ledbetter, J.O. and E.F. Gloyna : Predictive Techniques for Water Quality Inorganics, Proc. of ASCE, Vol. 90, No. SA. 1, pp. 127 151, 1964.

4) Gunnerson, C.G. : Streamflow and Quality in the COLUMBIA River Basin, Proc. of ASCE, Vol. 93, No. SA 6, pp. 1 16, 1967.

5) Steele, T.D. and M.E. Jennings : Regional Analysis of Streamflow Chemical Quailty in TEXAS, Water Resources Research, Vol. 8, No. 2, pp. 460 477, 1972 .

6）羽田守夫：雄物川の融雪期の污濁流出量について, 第 30 回土木学会年次学術講演会講演集第 2 部, pp. 606 607, 1975.

7）羽田守夫：水文学的資料による河川水質の評価について, 第 13 回下水道研究発表会講演集, pp. 473 475, 1976.

8）加藤武雄・志田 勇：吾妻火山松川上流地域に括ける酸性 河川の溶存物質流送作用, 東北地域災害科学研究, Vol. 10, pp. 15 21, 1973.

9）寺島 泰・塚本勝典・金津 清 : 淀川水質変動の統計的諸 性質について, 第 27 回土木学会年次学術講演会講演集第 2 部, pp. 595 596, 1972.

10）市川 新・横山道子：河川に打ける水質と流量との関係に ついて, 第 11 回下水道研究発表会講演集, pp. $428 \sim 430$, 1974.

11) McElroy, A.D., S.Y. Chiu, J.W. Nebgen, A. Aleti and A.E. Vandegrift: Water Pollution from Nonpoint Sources, Water Research, Vol. 9, pp. 675 $681,1975$.

12）市川 新・池田三郎：発見的自己組織化法による水質予 測, 土木学会論文報告集, No. 246, pp. 47 56, 1976.

13）石黑政儀・渡辺義公：自然河川における 濁質粒子の挙動 について, 第 29 回土木学会 年次学術講演会講演集 第 2 部, pp. 633 634, 1974.

14) Beston, R.P. and W.M. McMaster : Nonpoint Source Mineral Water Quality Model, Journal WPCF, Vol. 47, No. 10, pp. 2461 2473, 1975.

15) Haith D.A : Land Use and Water Quality in NEW YORK Rivers, Proc. of ASCE, Vol. 102, No. EE. 1, pp. 1 15, 1976.

16）広崎昭太・諏訪隆之：河川・用水の水質污濁と都市化と の関係についての多变量解析, 数理科学, No. 117, pp. $44 \sim 50,1973$.

17）建設省河川局 : 水質年表, 1973 .

18）小林 純：水の健康診断, 岩波新書, pp. $58 \sim 59,1971$.

(1976.7.12 - 受付) 